\title{
Translator's creativity in cultural elements transposition: a corpus-based study
}

\author{
La creatividad del traductor en la transposición de elementos culturales: \\ un estudio de corpus
}

\author{
Virginia Mattioli
}

Universitat Jaume I. al283328@uji.es

Received: 20/04/2017. Accepted: 9/11/2017

Resumen: En este artículo, se presenta un estudio basado en corpus con el objetivo de determinar el nivel de creatividad (frente al de convencionalismo) en la traducción de los elementos culturales. Considerando la creatividad como el uso de aquellas estrategias que manipulan el material léxico del texto de origen, se utilizó la metodología de la lingüística de corpus para examinar un corpus trilingüe (español, inglés, italiano) formado por 50 novelas ( 25 obras originales y las 25 traducciones correspondientes). La metodología adoptada se estructura en tres fases: (a) identificación de los elementos culturales, (b) determinación de las estrategias de traducción y (c) distinción entre técnicas creativas y convencionales. Los resultados demuestran que, por lo que se refiere a la transposición de los culturemas, los traductores propenden por las técnicas más creativas.

Palabras clave: lingüística de corpus; estudios de traducción; elementos culturales; creatividad; técnicas de traducción.

\begin{abstract}
This article presents a corpus-based study developed to determine the degree of creativity (as opposed to conventionalism) in the translation of cultural elements. Considering creativity as the use of those strategies that manipulate the lexical material of the source language, a literary corpus consisting of 50 novels ( 25 translations and 25 corresponding originals) was examined through corpus linguistics. Firstly, culture-specific elements were identified; secondly, translation strategies were determined; and finally, they were placed in conventional or creative groups. The results show that transposition of culture-specific elements is strictly related to creativity.
\end{abstract}

Keywords: corpus linguistics; translation studies; cultural elements; creativity; translation techniques.

》Mattioli, Virginia. 2017. "Translator's creativity in cultural elements transposition: a corpus-based study”. Quaderns de Filologia: Estudis Lingüístics 22: 187-213. doi: 10.7203/qf.22.11308 



\section{Introduction}

This article aims to assess translators' creativity in relation to culture-specificity in a corpus of fiction novels by comparing translations with their corresponding original works. In fact, the morphology of culture-specific elements suggests that the cultural nature of such lexical items determines which translation techniques are adopted to transpose them from one language to another.

After a brief introduction regarding the theoretical frame and the methodology adopted, this paper describes the analysis carried out to demonstrate the existence of such a relationship and translators' tendency to creativity.

Thus, in section one, corpus linguistics is presented and justified as the methodology chosen for the research; then cultural elements are introduced through a chronological presentation of previous authors' attempts to recognize and translate them; and finally, the concept of creativity is defined and compared with that of conventionalism. In section two, the case of study is described. Here, the specific hypothesis and objective of the research are presented, the corpus used is shown, and the various phases of the analysis are explained. Lastly, the outcomes are presented and the results are discussed. The article ends with some concluding remarks and suggestions for possible future research.

\section{Theoretical frame}

\subsection{Corpus linguistics in translation studies}

Since ancient times, a corpus has been defined as a collection of texts used to study common textual features. In the 1990s, Sinclair (1991: 171) underlined the nature of those texts, which should be natural (produced by human beings) and authentic (produced for real contexts). In the following years, several authors tried to propose a definition of corpus taking into account all the characteristics presented by this set of texts. Given the multiplicity of features dealt with in this study, we have adopted the definition proposed by Sánchez (1995: 8-9). Considering its origin, purpose, composition, representativeness and extension, Sánchez defines a corpus as a collection of linguistic data systematized according to certain criteria, wide enough in range and depth to be representative of the whole language or of some of its varieties. Moreover, 
he highlights the value of electronic processing in providing data which yield varied and useful results for description and analysis.

Corpus linguistics was born at the beginning of the 20th century (although its effectiveness increased from the 1960s thanks to developments in computing), with the objective of studying the language from real examples (Sinclair 1991: 171). As in this study corpus linguistics methodology has been used to observe translators' behavior with respect to specific lexical elements, the main interest here is the application of this methodology to translation studies and lexicology. Hence, according to translation studies scholars, corpus linguistics is very useful (a) to analyze the relationship between source and target text, in particular to describe the translation techniques chosen by translators (Lepinette, 2004: 2-3), and (b) to investigate translated language regularities and behaviors, observing translation processes, products and functions (Xiao and Ming, 2009: 237 Toury, 1995: 265 cit. Xiao \& Ming 2009: 237). On the other hand, from a lexicological perspective, by using corpus linguistics one can study word frequency, presence, use, characteristics, distribution and collocations (Procházková, 2006: 7-8).

In recent decades, there has been much debate regarding the nature of corpus linguistics and, considering its definition and objectives, several authors have questioned whether it should be treated as a discipline or a methodology.

In this study, priority has been given to the multiplicity of applications of corpus linguistics and, concurring with numerous authors (Leech, 1992: 105; McEnery and Wilson, 1996: 2 among others), it has been considered a methodology - more specifically, an empirical methodology based on the fact that language is a probabilistic system in which distinct features appear with different frequency. Considering both the advantages and the shortcomings of corpus linguistics, its application seems convenient for this research on two fronts: on the one hand, it facilitates identification of culture-specific elements and on the other, the fact that it permits us to analyze a great variety of texts guarantees a broad variety of authorities, topics and translators.

\subsection{Cultural elements}

Since the 1960s, several scholars of translation studies have demonstrated an increasing interest in cultural elements. Following Nida's 
first approach in 1964, many other authors focused their attention on these lexical items and the challenge they represent during the translation process. The main aims of such studies can be condensed into two groups according to their main objectives. On the one hand, those authors who attempt to define and classify cultural elements proposing various definitions, apparently without reaching any agreement about their nature and their identification. On the other, those who propose different techniques to transfer such elements from one language to another.

\subsubsection{Definition and classification of cultural elements}

Among the former, Nida (1945) recognizes cultural elements as a problem in translation and classifies them in five basic categories. Some years later, Newmark (1988) denominates these elements cultural words and introduces the concept of cultural language referred to the specific language of a certain culture within which it is possible to find a wide variety of culture-specific vocabulary (Newmark, 1988: 94). After him, Mayoral Asensio (1994: 76) labels as cultural references (referencias culturales) those elements of the discourse that, because of their reference to the original culture, are completely or partly misunderstood by the members of the target culture, and Aixelá (1996) focuses on the absence of these elements in the target culture. Christiane Nord (1997) adopts Vermeer's denomination and definition of cultureme as a "social phenomenon of a culture $\mathrm{X}$ that is regarded as relevant by members of this culture and, when compared with a corresponding social phenomenon in a culture Y, is found to be specific to culture X" (Vermeer, 1980; cfr. Nord 1997: 34). Finally, in this century, Santamaria (2001) defines and organizes cultural references in a detailed classification consisting of numerous categories and subcategories.

As this diachronic presentation of the studies regarding culture-specific items suggests, it seems that no agreement has been reached among the authors and that none of them explains clearly how to recognize a culture-specific element within a text. Moreover, some scholars focus on the changeable nature of cultural elements over time and following linguistic changes. In this sense, Molina Martínez (2001) considers that they exist only in those situations characterized by a cultural transfer -that is, in a translational context. 
As a result, it seems that the most commonly accepted characteristics of culture-specific elements are their specificity with respect to the original culture; their absence in the target culture; and their connotative value. Considering that the authors' divergent positions and the lack of a proper definition of culture-specific elements make it impossible to determine systematically whether they present or not a cultural nature, in this study they have been identified through their morphological structure (i.e. formation process, construction and origin of a word). In fact, the use in a language $\mathrm{X}$ of words borrowed from other languages implies the absence of such terms in the patrimonial vocabulary of the language X. According to Delwey (1950: 60-61 cit. Molina Martínez 2001: 23), language is a product of culture; hence, the absence in language $\mathrm{X}$ of a word to define an object or concept denotes the absence of such an object or concept in the X culture. Consequently, words imported from a language $\mathrm{Y}$ to a language $\mathrm{X}$ designate objects or concepts that originally belong to the $\mathrm{Y}$ culture and that therefore can be considered culturally specific to the Y culture. In this paper, therefore, culture-specific elements are taken to be all those words that present a morphological structure alien to the word formation rules of the language of the analyzed text (imported from a different language, thus from a different culture). Some examples of culture-specific elements identified in the novels translated into Italian and analyzed in the study are "bistrot", "whisky" and "sari" - words borrowed from foreign languages to designate objects that did not exist in the contemporary Italian culture (hence the lack of an Italian word to label them) - that represent respectively the French, Scottish and Indian cultures.

\subsubsection{Treatment and translation of cultural elements}

As regards the treatment of cultural elements, Nida (1964) initially proposes three basic methods to translate these references -addition, omission and conversion - to which he later adds some other solutions. His attempt is followed by Vázquez Ayora (1977: 251-384), Newmark (1988: 103-104), and Molina Martínez (2006), among many others. With the same purpose, some scholars prefer to organize translation techniques along a continuum instead of classifying them in categories. Among these, Mangiron (2006) distributes translation techniques along a line, ordering them from the most faithful to the source language and 
culture (transposition) to the most adapted to the target culture (cultural adaptation).

Adopting terms coined by Venuti (1995), these two opposite extremes can be named respectively foreignization and domestication.

Some other authors, instead, study the factors that influence the choice of the most appropriate translation technique among the ones suggested. In this sense, the precursor is Newmark (1998: 103), who in 1988 focused on six factors -text finality, readers' motivation and cultural level, importance of the cultural reference in the original text, area of use, novelty and future of the term.

While all the authors analyzed seem to agree on the factors to be taken into account at the moment of the linguistic transfer, there are still many discordant proposals regarding possible translation solutions to overcome the problems created by the cultural differences. To resolve these controversies and try to consider the most ample gamut of techniques possible, in this study the two main kinds of proposals have been merged and a new taxonomy of translation techniques has been suggested. The proposal, shown in figure 1, is composed of 15 techniques ordered in a continuum, from the most exotic to the most domesticated, each one defined and exemplified below.

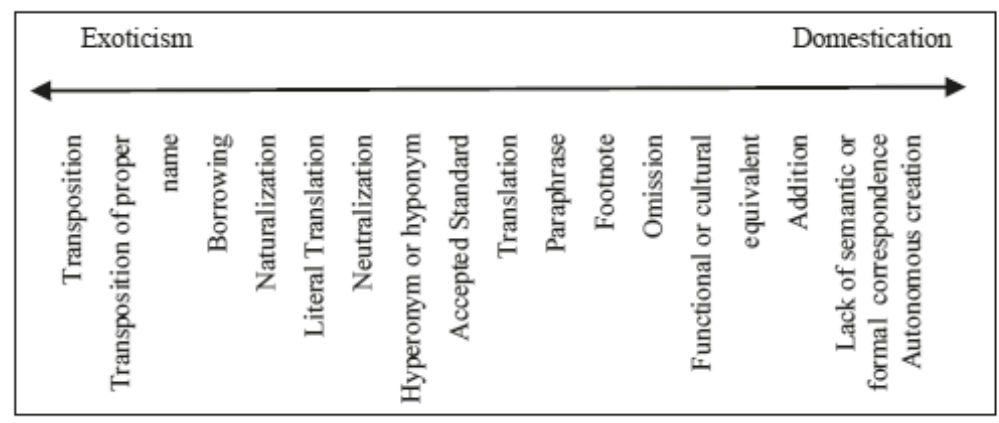

Fig. 1. Continuum of translation techniques used in the present study

- Transposition: maintenance of the original foreign word (Fish and Chips > Fish and Chips)

- Transposition of proper name: maintenance of the original proper name (Victoria street $>$ Victoria street) 
- Borrowing: maintenance of an original foreign word recognized by the dictionary of the target language $(\mathrm{Web}>\mathrm{Web})$

- Naturalization: adaptation to the target language phonetics (school bus $>$ scuolabus)

- Literal translation: literal translation of the culture-specific element (email > posta elettronica)

- Neutralization: explication by means of words that explain the function or the characteristics of the culture-specific element (turf > tappeto erboso del giardino)

- Hyperonym or hyponym: generalization or specification (respectively: bus station > stazione and knife > machete)

- Accepted standard translation: non-literal translation accepted by the vocabularies and the grammars of the target language (conference committee $>$ commissione congiunta)

- Paraphrase: addition of explication within the text (gondola $>$ gondola, a narrow Venetian boat)

- Footnote: addition of information in a footnote (prega Santa Lucia per recuperare la vista $>$ she prays to Saint Lucy to recover her sight ${ }^{1}-1$. Saint Lucy is considered the protector of sight, because of her name, Lucia, from the Latin word "lux" which means "light").

- Omission: omission of a culture-specific element (watching Friends on the TV > guardare la televisione)

- Functional or cultural equivalent: the use of a different element with the same cultural value of the original one (BA degree $>$ laurea triennale)

- Addition: addition of information absent in the source text (they drove back > tornarono indietro con la jeep)

- Lack of semantic or formal correspondence: translation presents a divergence of meaning or style with respect to the source text (respectively: on the corner of Sloane $\underline{\text { Street }>\text { all'angolo di piaz- }}$ $\underline{z a}$ Sloane and snatching from street $\underline{\text { urchins }}>$ furti dei bambini di strada)

- Autonomous creation: introduction of a cultural element that was absent in the source text (he sat and ate calmly $>$ si sedette e mangió con calma le sue tagliatelle ) 


\subsection{Creativity vs. conservationism}

Gil-Bardají (2003: 96), adopting Toury’s (1974; cit. Gil-Bardají, 2003) definition, considers norms as a set of regularities in a translator's behavior determined by a certain socio-cultural situation.

Kenny (2001: 66) transfers the concept of normalization to corpus-based translation studies and defines it as the use of conventional target translation solutions (opposed to the adoption of unusual source text features). The author adds that normalization can be applied at any language level and denominates the application of such techniques to individual words or collocations lexical normalization. So, Kenny (2001: 66) relates the idea of normalization to that of conventionalism. According to Corpas Pastor (2001), traditional (hence conventional) translation techniques are those that maintain a sort of equivalence between source and target text.

Despite the debatable nature of the concept of equivalence, in this study equivalence is observed from a formal and a semantic perspective, so items are considered equivalent (hence conventional) only when they present both a formal and semantic correspondence -respectively in terms of signifier and meaning. Hereafter, all those techniques characterized by some kind of omission, addition, manipulation or alteration of the original lexical material (see the previous section 2.2.2 for the techniques taxonomy adopted in this study) are considered not equivalent, thus not conventional, and consequently creative.

From here, in this paper translation strategies are divided into conventional and creative ones. The first group includes only literal translations, as they are the only ones that present a complete level of equivalence -both from a formal and a semantic point of view. On the opposite side, all the other techniques considered in the range presented in figure 1 are characterized by some kind of modification of the original material, so by some sort of nonequivalence (lexical, semantic or both), hence they are assigned to the creative strategies group.

This division enables us to observe and classify translators' behavior regarding culture-specific elements in terms of creativity: do they tend to maintain equivalence with the original elements (using literal translations) or do they prefer a more creative approach, modifying and manipulating the original items (using one of the techniques included in the creative strategies group)? 


\section{Case of study}

\subsection{Hypothesis and objectives}

The object of this research is to assess translators' creativity in relation to culture-specific elements. With this goal, corpus linguistic methodology was used to observe this feature in a set of translated novels, starting from the hypothesis that translators prefer creative techniques to transpose culture-specific items -according to the division between creative and conservative techniques proposed in the previous section. Actually, the relation between culture-specificity and foreign morphological structure (explained in section 2.2) seems to support this supposition. To corroborate this hypothesis, three semantic classes of culture-specific items were considered: (a) food and drinks, such as "curry", "bistrot" or "cognac" (b) communication and transportation, like "jeep", "parkway" or "roulotte" and (c) clothes and body care, e.g. "tweed", "gilet" or "sari". Once the items had been identified in a balanced and representative corpus, the techniques used to translate them were established by comparing aligned originals with translations. Finally, the results were observed to establish translators' preference for creative or conservative behavior.

\subsection{Corpus used}

The corpus used in the study, named LIT_TRAD, is compounded of two parallel subcorpora of award-winning fiction novels published between 2000 and 2014 and translated from English and Spanish into Italian. The two sets of novels are denominated LIT_TRAD_EN_IT - which includes 26 novels (13 English originals and 13 Italian translations) and LIT_TRAD_ES_IT - which is formed of 24 novels (12 Spanish originals and 12 Italian translations)-. Table 1 shows the details of the works included (original and translated versions) and their distribution within the two subcorpora: 


\begin{tabular}{|c|c|c|c|c|c|c|}
\hline & \multicolumn{3}{|c|}{ Original Novels } & \multicolumn{3}{|c|}{ Translations } \\
\hline Subcor- & \multicolumn{3}{|c|}{ Original_en and Original_es } & \multicolumn{3}{|c|}{ Target_en_it and Target_es_it } \\
\hline $\begin{array}{c}\text { Linguistic } \\
\quad \text { Pairs }\end{array}$ & Author & Title & $\begin{array}{c}\text { Year of } \\
\text { Publica- } \\
\text { tion }\end{array}$ & Translator & Title & $\begin{array}{c}\text { Year of } \\
\text { Publica- } \\
\text { tion }\end{array}$ \\
\hline \multirow[t]{13}{*}{$\mathrm{EN}>\mathrm{IT}$} & $\begin{array}{l}\text { Atwood, } \\
\text { Margaret }\end{array}$ & $\begin{array}{l}\text { Oryx and } \\
\text { Crake }\end{array}$ & 2003 & $\begin{array}{l}\text { Belletti, } \\
\text { Raffaella }\end{array}$ & $\begin{array}{l}\text { L'ultimo } \\
\text { degli uo- } \\
\text { mini }\end{array}$ & 2003 \\
\hline & Auster, Paul & $\begin{array}{l}\text { The } \\
\text { Brooklyn } \\
\text { follies }\end{array}$ & 2005 & $\begin{array}{l}\text { Bocchiola, } \\
\text { Massimo }\end{array}$ & $\begin{array}{l}\text { Le follie di } \\
\text { Brooklyn }\end{array}$ & 2005 \\
\hline & $\begin{array}{l}\text { Banville, } \\
\text { Jhon }\end{array}$ & The sea & 2005 & $\begin{array}{l}\text { Kamp- } \\
\text { mann, Eva }\end{array}$ & Il mare & 2006 \\
\hline & $\begin{array}{l}\text { Coetzee, } \\
\text { Jhon Max- } \\
\text { well }\end{array}$ & $\begin{array}{l}\text { Elizabeth } \\
\text { Costello }\end{array}$ & 2003 & $\begin{array}{l}\text { Baiocchi, } \\
\text { Maria }\end{array}$ & $\begin{array}{l}\text { Elizabeth } \\
\text { Costello }\end{array}$ & 2003 \\
\hline & $\begin{array}{l}\text { Cunning- } \\
\text { ham, Mi- } \\
\text { chael }\end{array}$ & $\begin{array}{l}\text { Specimen } \\
\text { days }\end{array}$ & 2005 & $\begin{array}{l}\text { Cotroneo, } \\
\text { Ivan }\end{array}$ & $\begin{array}{l}\text { Giorni } \\
\text { memorabili }\end{array}$ & 2005 \\
\hline & $\begin{array}{l}\text { De Lillo, } \\
\text { Don }\end{array}$ & $\begin{array}{l}\text { Cosmopo- } \\
\text { lis }\end{array}$ & 2003 & $\begin{array}{l}\text { Pareschi, } \\
\text { Silvia }\end{array}$ & Cosmopolis & 2003 \\
\hline & Desai, Anita & $\begin{array}{l}\text { The artist } \\
\text { of disap- } \\
\text { pearance }\end{array}$ & 2011 & $\begin{array}{l}\text { Nadotti, } \\
\text { Anna }\end{array}$ & $\begin{array}{l}\text { L'artista } \\
\text { della } \\
\text { sparizione }\end{array}$ & 2013 \\
\hline & $\begin{array}{l}\text { Ghosh, } \\
\text { Amitav }\end{array}$ & $\begin{array}{l}\text { The hun- } \\
\text { gry tide }\end{array}$ & 2004 & $\begin{array}{l}\text { Nadotti, } \\
\text { Anna }\end{array}$ & $\begin{array}{l}\text { Il paese } \\
\text { delle maree }\end{array}$ & 2005 \\
\hline & $\begin{array}{l}\text { Lessing, } \\
\text { Doris }\end{array}$ & $\begin{array}{l}\text { Alfred and } \\
\text { Emily }\end{array}$ & 2008 & $\begin{array}{l}\text { Pareschi, } \\
\text { Monica }\end{array}$ & $\begin{array}{l}\text { Alfred e } \\
\text { Emily }\end{array}$ & 2010 \\
\hline & $\begin{array}{l}\text { Morrison, } \\
\text { Toni }\end{array}$ & Home & 2012 & $\begin{array}{l}\text { Fornasiero, } \\
\text { Silvia }\end{array}$ & A casa & 2012 \\
\hline & $\begin{array}{l}\text { Potok, } \\
\text { Chaim }\end{array}$ & $\begin{array}{l}\text { Old men at } \\
\text { midnight }\end{array}$ & 2001 & $\begin{array}{l}\text { Muzzarel- } \\
\text { li, Mara }\end{array}$ & $\begin{array}{l}\text { Vecchi a } \\
\text { mezzanotte }\end{array}$ & 2002 \\
\hline & Roth, Philip & $\begin{array}{l}\text { The plot } \\
\text { against } \\
\text { America }\end{array}$ & 2004 & $\begin{array}{l}\text { Man- } \\
\text { tovani, } \\
\text { Vincenzo }\end{array}$ & $\begin{array}{l}\text { Il complot- } \\
\text { to contro } \\
\text { l'America }\end{array}$ & 2005 \\
\hline & $\begin{array}{l}\text { Suraiprasad } \\
\text { Naipaul, } \\
\text { Vidiadhar }\end{array}$ & Half a life & 2001 & $\begin{array}{l}\text { Cavagnoli, } \\
\text { Franca }\end{array}$ & $\begin{array}{l}\text { La metà di } \\
\text { una vita }\end{array}$ & 2002 \\
\hline
\end{tabular}




\begin{tabular}{|c|c|c|c|c|c|c|}
\hline & \multicolumn{3}{|c|}{ Original Novels } & \multicolumn{3}{|c|}{ Translations } \\
\hline Subcor- & \multicolumn{3}{|c|}{ Original_en and Original_es } & \multicolumn{3}{|c|}{ Target_en_it and Target_es_it } \\
\hline $\begin{array}{l}\text { Linguistic } \\
\quad \text { Pairs }\end{array}$ & Author & Title & $\begin{array}{c}\text { Year of } \\
\text { Publica- } \\
\text { tion }\end{array}$ & Translator & Title & $\begin{array}{c}\text { Year of } \\
\text { Publica- } \\
\text { tion }\end{array}$ \\
\hline \multirow[t]{12}{*}{$\mathrm{ES}>\mathrm{IT}$} & $\begin{array}{l}\text { Bryce } \\
\text { Echenique, } \\
\text { Alfredo }\end{array}$ & $\begin{array}{l}\text { El huerto } \\
\text { de mi } \\
\text { amada }\end{array}$ & 2002 & $\begin{array}{l}\text { Bovaia, } \\
\text { Roberta }\end{array}$ & $\begin{array}{l}\text { Il giardino } \\
\text { della mia } \\
\text { amata }\end{array}$ & 2003 \\
\hline & $\begin{array}{l}\text { Cercas, } \\
\text { Javier }\end{array}$ & $\begin{array}{l}\text { Soldados } \\
\text { de Sa- } \\
\text { lamina }\end{array}$ & 2001 & $\begin{array}{l}\text { Cacucci, } \\
\text { Pino }\end{array}$ & $\begin{array}{l}\text { Soldati di } \\
\text { Salamina }\end{array}$ & 2002 \\
\hline & $\begin{array}{l}\text { Marías, } \\
\text { Javier }\end{array}$ & $\begin{array}{l}\text { Los enamo- } \\
\text { ramientos }\end{array}$ & 2011 & $\begin{array}{l}\text { Felici, } \\
\text { Glauco }\end{array}$ & $\begin{array}{l}\text { Gli innamo- } \\
\text { ramenti }\end{array}$ & 2012 \\
\hline & $\begin{array}{l}\text { Montero, } \\
\text { Rosa }\end{array}$ & $\begin{array}{l}\text { La loca de } \\
\text { la casa }\end{array}$ & 2003 & $\begin{array}{l}\text { Finassi } \\
\text { Parolo, } \\
\text { Michela }\end{array}$ & $\begin{array}{l}\text { La pazza di } \\
\text { casa }\end{array}$ & 2004 \\
\hline & $\begin{array}{l}\text { Muñoz } \\
\text { Molina, } \\
\text { Antonio }\end{array}$ & $\begin{array}{l}\text { El viento } \\
\text { de la luna }\end{array}$ & 2006 & $\begin{array}{l}\text { Nicola, } \\
\text { Maria }\end{array}$ & $\begin{array}{l}\text { Il vento } \\
\text { della luna }\end{array}$ & 2008 \\
\hline & $\begin{array}{l}\text { Piglia, Ri- } \\
\text { cardo }\end{array}$ & $\begin{array}{l}\text { Blanco } \\
\text { Nocturno }\end{array}$ & 2011 & Cacucci, P. & $\begin{array}{l}\text { Bersaglio } \\
\text { notturno }\end{array}$ & 2011 \\
\hline & $\begin{array}{l}\text { Restrepo, } \\
\text { Laura }\end{array}$ & Delirio & 2004 & Simini, D. & Delirio & 2005 \\
\hline & Rosa, Isaac & $\begin{array}{l}\text { El vano } \\
\text { ayer }\end{array}$ & 2005 & $\begin{array}{l}\text { Annabella } \\
\text { Cardinali }\end{array}$ & Il vano ieri & 2007 \\
\hline & $\begin{array}{l}\text { Skarmeta, } \\
\text { Antonio }\end{array}$ & $\begin{array}{l}\text { El baile de } \\
\text { la victoria }\end{array}$ & 2003 & $\begin{array}{l}\text { Collo, } \\
\text { Paolo }\end{array}$ & $\begin{array}{l}\text { Il ballo } \\
\text { della vit- } \\
\text { toria }\end{array}$ & 2005 \\
\hline & $\begin{array}{l}\text { Vargas } \\
\text { Llosa, Mario }\end{array}$ & $\begin{array}{l}\text { Travesuras } \\
\text { de la niña } \\
\text { mala }\end{array}$ & 2006 & $\begin{array}{l}\text { Felici, } \\
\text { Glauco }\end{array}$ & $\begin{array}{l}\text { Le avven- } \\
\text { ture della } \\
\text { ragazza } \\
\text { cattiva }\end{array}$ & 2006 \\
\hline & $\begin{array}{l}\text { Vazquez } \\
\text { Montalbán, } \\
\text { Manuel }\end{array}$ & $\begin{array}{l}\text { El hombre } \\
\text { de mi vida }\end{array}$ & 2000 & $\begin{array}{l}\text { Hado, } \\
\text { Lyria }\end{array}$ & $\begin{array}{l}\text { L'uomo } \\
\text { della mia } \\
\text { vita }\end{array}$ & 2000 \\
\hline & $\begin{array}{l}\text { Vila-Matas, } \\
\text { Enrique }\end{array}$ & $\begin{array}{l}\text { El viaje } \\
\text { vertical }\end{array}$ & 2001 & $\begin{array}{l}\text { Cattaneo, } \\
\text { S. }\end{array}$ & $\begin{array}{l}\text { Il viaggio } \\
\text { verticale }\end{array}$ & 2006 \\
\hline
\end{tabular}

Table 1. Composition of LIT_TRAD 
After a close study of the literature on corpus compilation, the works to be included in the collection were chosen according to the following criteria:

- Representativeness (from a qualitative and quantitative point of view). Firstly, all the novels selected had been awarded international literary prizes, to satisfy the qualitative representativeness criterion. Then, once the corpus had been compiled, its quantitative representativeness was assessed using ReCor (Corpas Pastor, Seghiri, Maggi 2006), a statistical program specifically developed to evaluate the quantitative representativeness of a corpus a posteriori, according to the number of words and of texts that it includes.

- Inclusion of whole texts: to achieve the aim of the study, identifying as many culture-specific elements as possible.

- Balance: the two subcorpora include the same number of works and, despite the inclusion of entire texts, they are still comparable as regards the number of words.

- Variability: the original novels selected are written in different varieties of English and Spanish to guarantee a high level of variability.

- Authenticity: the texts included are literary works written for real contexts by native authors.

To facilitate the identification of the culture-specific elements, the corpus was semantically tagged using USAS (UCREL Semantic Analysis System) developed by the UCREL research group of the University of Lancaster (Piao et al., 2016). This tagging system adds after each word an underscore followed by a code formed of numbers and letters (e.g. _F1 for food related words).

\subsection{Analysis}

The two subcorpora were analyzed separately and at the end, results were compared. The analytic process can be divided into 4 steps:

1. Selection of the culture-specific elements 
2. Comparison of the translated culture-specific elements with the corresponding original items

3. Determination of the translation technique used in each case

4. Comparison between the results obtained from the two subcorpora.

Various programs and tools were used to analyze the texts.

In the first phase, a word list was created for each target corpus (TARGET_EN_IT and TARGET_ES_IT) using AntConc (Anthony, 2014). Then, the terms related to the three semantic categories considered in this study (see section 3.2) were identified in the lists. This process was facilitated by the format of the semantic tagging used. In fact, searching for each tag in the concordance list, the outputs present the searched node in the middle of each line (in blue in the screenshot in figure 2 below), and on its left all the terms included in the related semantic category (in red in the screenshot in figure 2).

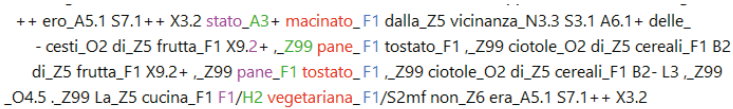

++ ero_A5.1 S7.1 ++ X3.2 stato_A3 + macinato_F1 dalla_Z5 vicinanza_N3.3 S3.1 A6.1 + delle_ - cesti_O2 di_Z5 frutta_F1 X9.2 + ,_Z99 pane_F1 tostato_F1, _Z99 ciotole_O2 di_Z5 cereali_F1 B2 di_Z5 frutta_F1 X9.2+ ,_Z99 pane_F1 tostato_F1 ,_Z99 ciotole_O2 di_Z5 cereali_F1 B2- L3 ,_Z99 _O4.5 ._Z99 La_Z5 cucina_F1 F1/H2 vegetariana_F1/S2mf non_Z6 era_A5.1 S7.1 + + X3.2 - L3 ,_Z99 vasi_O2 O1.1 H5 di_Z5 yogurt_F1 fatto_A1.1.1 G2.2- X9.2 + in_M6

Fig. 2. Extract from the results of the search for the semantic tag F1 (food) in TARGET_EN_IT in AntConc (Anthony, 2014)

Among the words belonging to each semantic field considered, only culture-specific elements were selected manually according to their morphological structure (only the words with a foreign morphology were chosen). To follow the example given in figure 2, among the words related to the semantic field of food (in red) -identified by means of the search for tag F1-, only the ones with a foreign morphological structure were chosen, thus only the word "yogurt".

Among the elements specific to foreign cultures (which present a foreign morphological structure), those items that are specific to Italian culture were also considered, to observe their treatment in the transfer from the source languages studied to the Italian target language: are they present in the foreign novels, or are they added by Italian translators? And if they are present in the source text, which techniques does the translator use to transpose them into Italian without losing their exotic 
Italian-style function (if any)? With this objective, also those words with an Italian morphological structure that are frequently used in foreign languages (like "panini", "vespa" or "spaghetti") were included.

Finally, the elements of the resulting lists were subjected to a further selection in order to assure a high level of representativeness and to exclude from the study the terms that do not represent any specific culture. This selection excluded the following culture-specific elements from the analysis:

- those items with a frequency lower than 10 occurrences;

- those items that appear in fewer than three different novels;

- those items that could not be considered culture-specific elements, despite presenting a morphological structure external to Italian grammar, because of their complete assimilation into Italian daily life and language, as demonstrated by a high frequency in general Italian corpora (e.g. jeans, computer, internet, etc.).

As a result, only the elements that satisfied these criteria were analyzed.

The complete lists of the culture-specific elements resulting from this selection process that were analyzed in the present study are presented in tables 2 and 3 :

\begin{tabular}{|l|c|l|c|}
\hline $\begin{array}{c}\text { Culture-Specific } \\
\text { Element }\end{array}$ & Frequency & \multicolumn{1}{|c|}{ Semantic Class } & $\begin{array}{c}\text { Original } \\
\text { Language }\end{array}$ \\
\hline Avenue & 157 & Communication and Transportation & FR \\
\hline Street & 157 & Communication and Transportation & EN \\
\hline Taxi & 67 & Communication and Transportation & FR \\
\hline Sari & 49 & Clothing and Body care & HI \\
\hline Camion & 43 & Communication and Transportation & FR \\
\hline Autobus & 42 & Communication and Transportation & FR \\
\hline Garage & 40 & Communication and Transportation & FR \\
\hline Station & 37 & Communication and Transportation & EN \\
\hline Road & 31 & Communication and Transportation & EN \\
\hline Square & 29 & Communication and Transportation & EN \\
\hline Pullman & 25 & Communication and Transportation & EN \\
\hline Jeep & 23 & Communication and Transportation & EN \\
\hline
\end{tabular}




\begin{tabular}{|l|c|l|c|}
\hline $\begin{array}{c}\text { Culture-Specific } \\
\text { Element }\end{array}$ & Frequency & \multicolumn{1}{|c|}{ Semantic Class } & $\begin{array}{c}\text { Original } \\
\text { Language }\end{array}$ \\
\hline Scotch & 23 & Food and drink & EN \\
\hline Picnic & 18 & Food and drink & EN \\
\hline Vodka & 18 & Food and drink & RU \\
\hline Whisky & 16 & Food and drink & EN \\
\hline Toast & 17 & Food and drink & EN \\
\hline Champagne & 14 & Food and drink & FR \\
\hline Brandy & 14 & Food and drink & EN \\
\hline Parkway & 14 & Food and drink & EN \\
\hline Pizza & 14 & Communication and Transportation & IT \\
\hline Sandwich & 13 & Food and drink & EN \\
\hline Slogan & 12 & Clothing and Body care & EN \\
\hline Mais & 12 & Communication and Transportation & FR \\
\hline $\begin{array}{l}\text { Berretto da } \\
\text { baseball }\end{array}$ & 10 & Food and drink & EN \\
\hline Roulotte & 10 & Communication and Transportation & FR \\
\hline Curry & Clothing and Body care & EN \\
\hline Tunnel & 10 & & \\
\hline Tweed & 14 & \\
\hline TOTAL & 14 & FR & \\
\hline
\end{tabular}

Table 2. Culture-specific elements selected for the analysis in LIT_TRAD_EN_IT

\begin{tabular}{|l|c|l|c|}
\hline $\begin{array}{c}\text { Cultur-Specific } \\
\text { Element }\end{array}$ & Frecuency & \multicolumn{1}{|c|}{ Semantic Class } & $\begin{array}{c}\text { Original } \\
\text { Language }\end{array}$ \\
\hline Calle & 163 & Communication and Transportation & ES \\
\hline Taxi & 105 & Communication and Transportation & FR \\
\hline Avenida & 58 & Communication and Transportation & ES \\
\hline Autobus & 51 & Communication and Transportation & FR \\
\hline Champagne & 49 & Food and drinks & FR \\
\hline Whisky & 39 & Food and drinks & EN \\
\hline Bistrot & 29 & Food and drinks & FR \\
\hline Camion & 23 & Communication and Transportation & FR \\
\hline Panini & 20 & Food and drinks & IT \\
\hline Gin & 16 & Food and drinks & EN \\
\hline
\end{tabular}




\begin{tabular}{|l|c|l|c|}
\hline $\begin{array}{c}\text { Cultur-Specific } \\
\text { Element }\end{array}$ & Frecuency & \multicolumn{1}{|c|}{ Semantic Class } & $\begin{array}{c}\text { Original } \\
\text { Language }\end{array}$ \\
\hline Sandwich & 16 & Food and drinks & EN \\
\hline Reportage & 14 & Communication and Transportation & FR \\
\hline Tunnel & 13 & Communication and Transportation & EN \\
\hline Gilet & 12 & Clothing and body care & FR \\
\hline Cognac & 11 & Food and drinks & FR \\
\hline Dessert & 10 & Food and drinks & FR \\
\hline TOTAL & $\mathbf{6 2 9}$ & & \\
\hline
\end{tabular}

Table 3. Culture-specific elements selected for the analysis in LIT_TRAD_ES_IT

Tables 4 and 5 show the number of elements identified in each step of this first phase of analysis for each subcorpus (the number of elements included in the three semantic classes chosen, the culture-specific elements identified among them and the most representative ones selected for the analysis):

\begin{tabular}{|c|c|c|c|c|c|c|c|c|c|}
\hline & & \multicolumn{2}{|c|}{ Total } & \multicolumn{2}{|c|}{$\begin{array}{c}\text { Food and } \\
\text { Drink }\end{array}$} & \multicolumn{2}{|c|}{$\begin{array}{c}\text { Clothes and } \\
\text { body care }\end{array}$} & \multicolumn{2}{|c|}{$\begin{array}{c}\text { Transportation } \\
\text { and communi- } \\
\text { cation }\end{array}$} \\
\hline & & Tot. & $\%$ & Tot. & $\%$ & Tot. & $\%$ & Tot. & $\%$ \\
\hline \multirow{2}{*}{$\begin{array}{l}\text { Semantic } \\
\text { elements }\end{array}$} & Tokens & 8969 & -- & 2248 & $25 \%$ & 2213 & $24 \%$ & 4507 & $50 \%$ \\
\hline & Types & 972 & -- & 385 & $40 \%$ & 267 & $27 \%$ & 320 & $33 \%$ \\
\hline \multirow{2}{*}{$\begin{array}{l}\text { Culture- } \\
\text { specific } \\
\text { elements } \\
\text { identified }\end{array}$} & Tokens & 1945 & $\begin{array}{c}22 \% \\
*\end{array}$ & 493 & $\begin{array}{c}22 \% \\
* *\end{array}$ & 253 & $\begin{array}{c}11 \% \\
* *\end{array}$ & 1199 & $\begin{array}{c}27 \% \\
* *\end{array}$ \\
\hline & Types & 285 & $\begin{array}{c}36 \% \\
*\end{array}$ & 138 & $\begin{array}{c}36 \% \\
* *\end{array}$ & 57 & $\begin{array}{c}21 \% \\
* *\end{array}$ & 90 & $\begin{array}{c}28 \% \\
* *\end{array}$ \\
\hline \multirow{2}{*}{$\begin{array}{l}\text { Culture- } \\
\text { specific } \\
\text { elements } \\
\text { analyzed }\end{array}$} & Tokens & 944 & $\begin{array}{l}49 \% \\
* * *\end{array}$ & 172 & $\begin{array}{l}35 \% \\
* * * *\end{array}$ & 71 & $\begin{array}{l}28 \% \\
* * * *\end{array}$ & 701 & $\begin{array}{l}58 \% \\
* * * *\end{array}$ \\
\hline & Types & 29 & $\begin{array}{l}10 \% \\
* * *\end{array}$ & 11 & $\begin{array}{c}8 \% \\
* * * *\end{array}$ & 3 & $\begin{array}{c}5 \% \\
* * * *\end{array}$ & 15 & $\begin{array}{l}17 \% \\
* * * *\end{array}$ \\
\hline
\end{tabular}

$* \%$ of the total semantic elements, ** \% of the total semantic elements of the category,

$* * * \%$ of the total culture-specific elements, $* * * * \%$ of the total culture-specific elements of the category

Table 4. Culture-specific elements identified in LIT_TRAD_EN_IT 


\begin{tabular}{|c|c|c|c|c|c|c|c|c|c|}
\hline & & \multicolumn{2}{|c|}{ Total } & \multicolumn{2}{|c|}{$\begin{array}{c}\text { Food and } \\
\text { Drink }\end{array}$} & \multicolumn{2}{|c|}{$\begin{array}{c}\text { Clothes and } \\
\text { body care }\end{array}$} & \multicolumn{2}{|c|}{$\begin{array}{c}\text { Transportation } \\
\text { and communi- } \\
\text { cations }\end{array}$} \\
\hline & & Tot. & $\%$ & Tot. & $\%$ & Tot. & $\%$ & Tot. & $\%$ \\
\hline \multirow{2}{*}{$\begin{array}{l}\text { Semantic } \\
\text { elements }\end{array}$} & Tokens & 7599 & -- & 2234 & $29 \%$ & 1923 & $25 \%$ & 3442 & $45 \%$ \\
\hline & Types & 997 & -- & 443 & $44 \%$ & 260 & $26 \%$ & 294 & $29 \%$ \\
\hline \multirow{2}{*}{$\begin{array}{l}\text { Culture- } \\
\text { specific } \\
\text { elements } \\
\text { identified }\end{array}$} & Tokens & 1594 & $\begin{array}{c}21 \% \\
*\end{array}$ & 588 & $\begin{array}{c}26 \% \\
* *\end{array}$ & 168 & $\begin{array}{l}9 \% \\
* *\end{array}$ & 838 & $\begin{array}{c}24 \% \\
* *\end{array}$ \\
\hline & Types & 348 & $\begin{array}{c}35 \% \\
*\end{array}$ & 184 & $\begin{array}{c}42 \% \\
* *\end{array}$ & 56 & $\begin{array}{c}22 \% \\
* *\end{array}$ & 108 & $\begin{array}{c}37 \% \\
* *\end{array}$ \\
\hline \multirow{2}{*}{$\begin{array}{l}\text { Culture- } \\
\text { specific } \\
\text { elements } \\
\text { analyzed }\end{array}$} & Tokens & 629 & $\begin{array}{l}39 \% \\
* * *\end{array}$ & 190 & $\begin{array}{l}32 \% \\
* * * *\end{array}$ & 12 & $\begin{array}{l}7 \% \\
* * * *\end{array}$ & 427 & $\begin{array}{l}50 \% \\
* * * *\end{array}$ \\
\hline & Types & 16 & $\begin{array}{l}5 \% \\
* * *\end{array}$ & 8 & $\begin{array}{c}4 \% \\
* * * *\end{array}$ & 1 & $\begin{array}{c}1 \% \\
* * * *\end{array}$ & 7 & $\begin{array}{c}6 \% \\
* * * *\end{array}$ \\
\hline
\end{tabular}

$* \%$ of the total semantic elements, $* * \%$ of the total semantic elements of the category, $* * * \%$ of the total culture-specific elements, $* * * * \%$ of the total culture-specific elements of the category

Table 5. Culture-specific elements identified in LIT_TRAD_ES_IT

The second and the third phases aimed to establish the translation technique used in each case, starting respectively from the target and the original text. These steps were carried out using the AntPConc program (Anthony, 2013), which searches for an item in one of the two aligned corpora and shows the resulting concordances in both of them.

The second phase, characterized by the search for the culture-specific elements identified in the target corpus, revealed the corresponding original form of each item. The screenshot in figure 3 shows the search for the item "roulotte", as an example of this step.

In the example in figure 3, the culture-specific element "roulotte" was searched for in the target corpus. By comparing the outcomes shown in the upper and the lower part of the screen (respectively, the results of the search in the target and the source corpus) it was possible to determine the corresponding original terms in the source corpus, in this case "trailer" and "caravan". The comparison also revealed whether the translator had added any culture-specific element originally absent in the source text (a case that would imply a high degree of translator's creativity). 


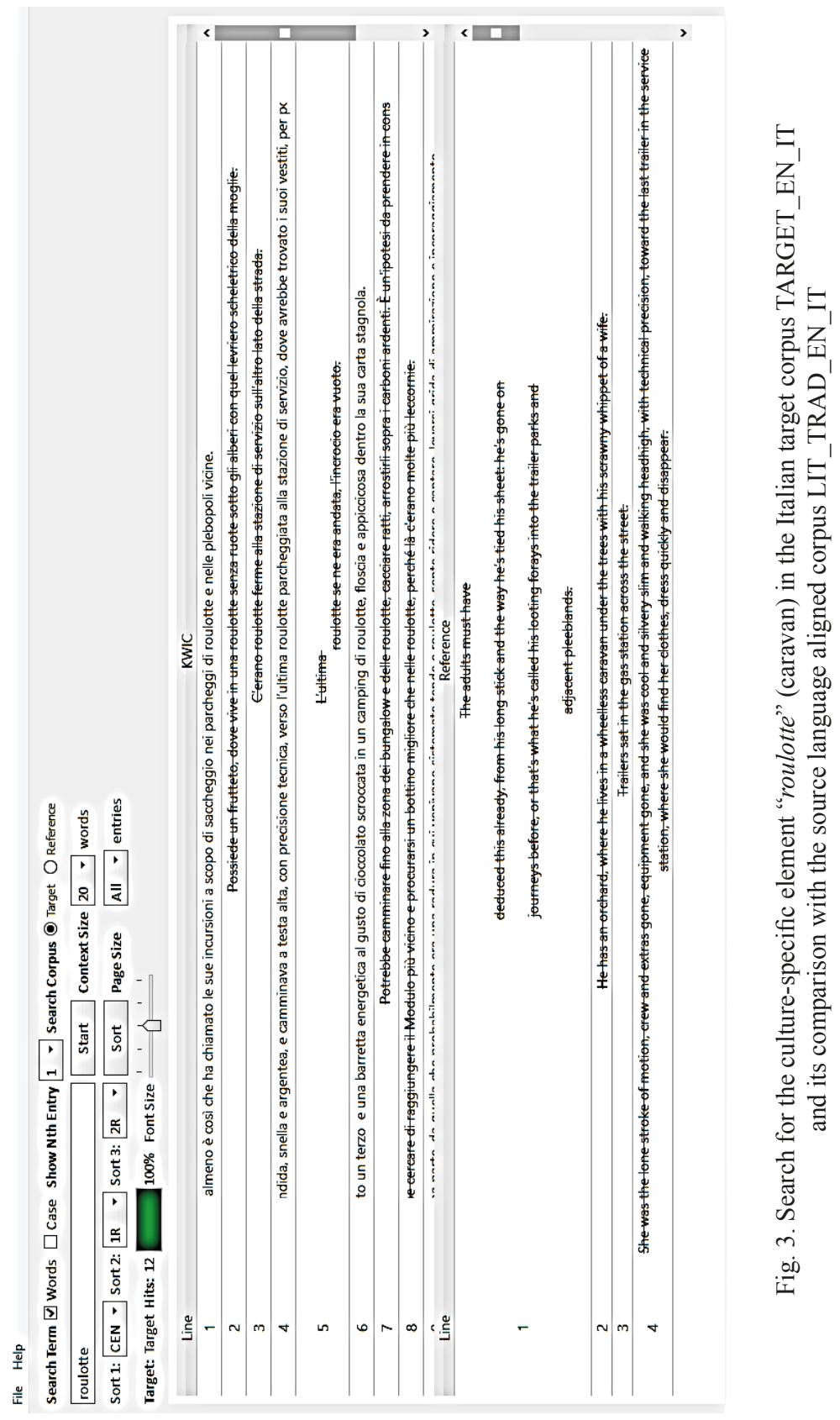


In the third phase, the original forms of each culture-specific element were searched for in the source corpus (following the example in figure 3, the words "caravan" and "trailer" were searched for in the source corpus). Through this search, it was possible to establish which of the translation techniques included in the proposed taxonomy presented in figure 1 had been used. The results obtained from the second and third phases of the analysis applied to each subcorpus are detailed in the following table (table 6):

\begin{tabular}{|c|c|c|c|c|}
\hline \multirow{3}{*}{ Techniques } & \multicolumn{4}{|c|}{ Occurrences } \\
\hline & \multicolumn{2}{|c|}{ LIT_TRAD_EN_IT } & \multicolumn{2}{|c|}{ LIT_TRAD_ES_IT } \\
\hline & occurrences & $\%$ & occurrences & $\%$ \\
\hline Transposition & 13 & \multirow{2}{*}{$33 \%$} & 0 & \multirow{2}{*}{$31 \%$} \\
\hline Transposition of proper name & 389 & & 222 & \\
\hline Borrowing & 630 & $53 \%$ & 306 & $43 \%$ \\
\hline Naturalization & 5 & $<1 \%$ & 2 & $<1 \%$ \\
\hline Literal translation & 60 & $5 \%$ & 89 & $12 \%$ \\
\hline Neutralization & 0 & $0 \%$ & 0 & $0 \%$ \\
\hline Hyperonym & 8 & $<1 \%$ & 8 & $1 \%$ \\
\hline Hyponym & 2 & $<1 \%$ & 1 & $<1 \%$ \\
\hline Standard accepted translation & 12 & $1 \%$ & 0 & $0 \%$ \\
\hline Paraphrase & 0 & $0 \%$ & 0 & $0 \%$ \\
\hline Footnote & 0 & $0 \%$ & 0 & $0 \%$ \\
\hline Omission & 21 & $2 \%$ & 8 & $1 \%$ \\
\hline $\begin{array}{l}\text { Cultural or functional equiva- } \\
\text { lent }\end{array}$ & 5 & $<1 \%$ & 6 & $<1 \%$ \\
\hline Addition & 15 & $1 \%$ & 27 & $4 \%$ \\
\hline $\begin{array}{l}\text { Lack of semantic or formal } \\
\text { equivalence }\end{array}$ & 13 & $1 \%$ & 9 & $1 \%$ \\
\hline Autonomous creation & 3 & $<1 \%$ & 0 & $0 \%$ \\
\hline Other techniques & 13 & $1 \%$ & 5 & $<1 \%$ \\
\hline
\end{tabular}

Table 6. Translation techniques used in LIT_TRAD

Considering the wide use of borrowings and transpositions, a further analysis was carried out to explore the origin of the foreign terms. In this case, translators' creativity was assessed according to the original- 
ity of such items with respect to the source text. To this end, different values were attributed to the elements adopted, depending on:

- whether a word had been adopted from the source language but it was absent in the original text (high level of creativity) (e.g. making his pitch from his knees > lanciando i suoi slogan in ginocchio)

- whether a source word had been transferred from the source to the target text through a borrowing or a transposition from a language different from the source one (mid level of creativity) (e.g. buttering corn bread > imburrava pane di mais)

- whether the foreign word used in the translation was the same one used in the source text (low level of creativity) (e.g. a cheap printed sari $>$ un modesto sari di tessuto stampato).

The detailed results of this comparison are presented in tables 7 and 8 below:

\begin{tabular}{|l|l|r|l|r|}
\hline \multicolumn{1}{|c|}{$\begin{array}{c}\text { Creativity } \\
\text { level }\end{array}$} & \multicolumn{1}{|c|}{ Translator's behavior } & \multicolumn{1}{c|}{ Type of technique } & \\
\hline $\begin{array}{l}\text { More } \\
\text { creativity }\end{array}$ & $\begin{array}{l}\text { Foreign elements added by the } \\
\text { translator }\end{array}$ & 32 & Borrowing & 31 \\
\cline { 2 - 5 } & $\begin{array}{l}\text { Foreign elements added from } \\
\text { languages other than the } \\
\text { source one }\end{array}$ & 156 & Borrowing & 156 \\
\cline { 2 - 5 } $\begin{array}{l}\text { Less } \\
\text { creativity }\end{array}$ & $\begin{array}{l}\text { Foreign element directly trans- } \\
\text { posed from the original text }\end{array}$ & 806 & Transposition & 413 \\
\cline { 2 - 5 } & & & Borrowing & 393 \\
\hline
\end{tabular}

Table 7: translator's creativity in the use of borrowings in LIT_TRAD_EN_IT

\begin{tabular}{|c|c|c|c|c|}
\hline $\begin{array}{l}\text { Creativity } \\
\text { level }\end{array}$ & Translator's behavior & & Type of technique & \\
\hline \multirow{2}{*}{$\begin{array}{l}\text { More } \\
\text { creativity }\end{array}$} & $\begin{array}{l}\text { Foreign elements added by the } \\
\text { translator }\end{array}$ & 1 & Borrowing & 1 \\
\hline & $\begin{array}{l}\text { Foreign elements added from } \\
\text { languages other than the } \\
\text { source one }\end{array}$ & 96 & Borrowing & 96 \\
\hline \multirow{2}{*}{$\begin{array}{l}\qquad \vee \\
\text { Less } \\
\text { creativity }\end{array}$} & \multirow{2}{*}{$\begin{array}{l}\text { Foreign element directly trans- } \\
\text { posed from the original text }\end{array}$} & \multirow{2}{*}{420} & Transposition & 221 \\
\hline & & & Borrowing & 199 \\
\hline
\end{tabular}

Table 8: translator's creativity in the use of borrowings in LIT_TRAD_ES_IT 
As a last step, the results obtained from the two subcorpora analyzed were compared.

\subsection{Discussion}

The outcomes of the analysis show that the quantity of culture-specific elements identified in the two subcorpora (LIT_TRAD_EN_IT and LIT_TRAD_ES_IT) is similar for both pairs of languages. However, the proportion of tokens to types is higher in the subcorpus of novels translated from English (1945 tokens and 285 types) than in the one composed of Spanish translations (1594 tokens and 348 types). This difference indicates that Spanish translations present a greater variety of culture-specific elements, each one with a lower number of occurrences. On the other hand, regarding the items analyzed, there is a significant quantitative difference between the two subcopora. In fact, after selection according to the representativeness and culture-specificity criteria (see section 3.3), in LIT_TRAD_EN_IT 29 culture-specific elements were analyzed (10\% of the total) while in LIT_TRAD_ES_IT only 16 (5\%) (see tables 4 and 5). This difference underpins the results obtained for the total culture-specific elements explained above: in LIT_TRAD ES_IT there is a greater variety of items with a lower frequency, so that only few of them met the representativeness criteria (being present in more than 3 novels and presenting at least 10 occurrences) and were selected for the analysis. With regard to culture specificity, there are no differences between the two subcorpora: in the English-Italian one, 4 elements were eliminated because of their assimilation into the target culture, and in the Spanish-Italian corpus, 5. It is interesting to note that the eliminated elements are the same in the two subcorpora (in both groups of texts the words "film", "computer", "jeans", "internet" and in LIT_TRAD_ES_IT also "yoghurt" were eliminated). These results also show that the words most assimilated into the Italian language and culture are the English ones (regardless of the source language of the texts). Because of the different number of elements, all the comparisons between the outcomes obtained in the two subcorpora are expressed in percentages.

Regarding the translation techniques used, as shown in table 6, the most commonly-used strategies are borrowings (used in 53\% of the cases in the novels translated from English and 43\% in those translated 
from Spanish) and transpositions (33\% and 31\% respectively, considering both transposition and transposition of proper names). On the other hand, literal translations had been used in only $5 \%$ of the occurrences in LIT_TRAD_EN_IT and 12\% in LIT_TRAD_ES_IT. These results confirm the initial hypothesis and demonstrate that in transposing culture-specific elements, translators tend more to creativity than to conventionalism.

Comparing the two language pairs considered, Spanish-into-Italian translators seem to be more faithful to the original text, thus presenting a lower level of creativity (considering creativity -opposed to conventionalism- as any kind of manipulation of the source text that causes any sort of nonequivalence: see section 2.3). In fact, LIT_TRAD_ES IT presents a lower percentage of borrowings than LIT_TRAD_EN_IT ( $43 \%$ as opposed to $53 \%)$ and a higher one of literal translations $(12 \%$ versus $5 \%$ ). Considering also the origin of such borrowings, the level of creativity is higher in translations from English than in those from Spanish. Actually, in LIT_TRAD_EN_IT, although the majority of the foreign words are transposed directly from the source text $(81 \%)$ or come from a language different from the source one -usually French$(15 \%)$, in $3 \%$ of the borrowings translators decided to add a word from English that was absent in the original texts, demonstrating a higher level of initiative and creativity. On the other hand, in LIT_TRAD_ES IT translators opted almost always to use the same terms as the original text or to substitute them with words from other languages (respectively in $81 \%$ and $19 \%$ of the use of foreign words), but in just one case $(0,2 \%)$ a borrowed word from Spanish that was absent in the original text was added to the translation (see tables 4 and 5). These results could be interpreted as being related to the socio-cultural prestige of the languages analyzed. English is a prestigious language in the centre of the polysystem (according to the polysystem theory proposed by Even Zohar, 1990), so it is less translated and translators tend to maintain English words in the target texts. On the other hand, Spanish is a marginal language in the polysystem with a low degree of socio-cultural prestige; consequently, translators are less interested in maintaining items from this language in the target texts and frequently exchange them with terms adopted from other languages which are external to the linguistic pair but more prestigious. 
These outcomes also suggest that the techniques used do not depend on the similarity or difference between the source and the target language, but on the degree of socio-cultural prestige of a language. Specifically, the greater use of literal translation in Spanish-Italian translations does not seem to depend on the affinity between Spanish and Italian (in fact, in translating into Italian from Spanish -a closer language than English to Italian- translators frequently opt to add many English words that are completely different from both the source and the target language, instead of maintaining a Spanish term more similar to the target language).

\section{Conclusions}

The aim of this study was to assess translators' creativity in the transposition of culture-specific elements. To reach this objective a corpus-based analysis was applied to a set of 25 translated novels focusing on the techniques chosen by translators to transpose culture-specific elements from certain semantic fields (food and drink, clothing and body care, and transportation and communication). The results of the analysis show that the most commonly used techniques are borrowings and transpositions. These outcomes corroborate the initial hypothesis, demonstrating that translators do indeed prefer to adopt creative techniques to transpose culture-specific items, and suggest that translation helps to enlarge target-language lexis from two perspectives. On the one hand, translators' choices tend to enlarge the vocabulary of the target language by importing terms from other languages and helping to increase their frequency of use. On the other, translation -as linguistic and cultural transfer- contributes to multiculturalism by enriching the target culture with words and concepts from the source language as well as from other different languages and cultures.

From a methodological perspective, the choice of a corpus linguistics method enabled us to reach the initial goal, and it proved a useful approach to identify culture-specific elements in an ample range of texts and analyze their translation techniques electronically, thanks to the use of several tools appropriate to each different phase and goal. These results appear to suggest two considerations regarding corpus-based methods: firstly, this methodology can be successfully applied to literary texts, and specifically to literary translation; secondly, the applica- 
tion of this method to lexical and terminological research shows itself to be highly effective.

This article is only a first approach to the study of creativity in the translation of lexical elements focusing on culture-specific items. It could be followed by further research into the role of translation in the adoption of new lexical units and in the extension of vocabulary. There is ample scope for continued investigation of translators' creativity in relation to culture-related items, from both perspectives: translation process (observing their transposition) and product (analyzing their form in the target language). In this sense, further analysis could focus on the study of other semantic categories of culture-specific items, on lexical elements related to the discourse of a specific culture, or on those lexical elements that represent the culture of specific social classes or groups. Moreover, the methodology proposed in this paper could be replicated to observe the characteristics of other lexical units -not necessary linked to culture-specificity- from the same translational perspective.

\section{References}

Aixelá, Javier Franco. 1996. Culture-specific Items in Translation. In Ávarez, Román \& Vidal, M. Carmen-África (eds.) Translation, Power Subversion. Clevedon, Philadelphia, Adelaide: Multilingual Matters, 52-78.

Anthony, Laurence. 2014. Antconc (Version 3.4.1) [Computer Software]. Tokyo, Japan: Waseda University. Http://www.antlab.sci.waseda.ac.jp/ [Accessed 01/12/2015].

Anthony, Laurence. 2013. AntPConc (Version 1.0.3) [Computer Software]. Tokyo, Japan: Waseda University. Http://www.antlab.sci.waseda.ac.jp/ [Accessed 01/12/2015].

Corpas Pastor, Gloria. 2001. La creatividad fraseológica: efectos semántico-pragmáticos y estrategias de traducción. Paremia 10: 67-78.

Corpas Pastor, Gloria; Seghiri Domínguez, Miriam \& Romano, Maggi. 2006. Recor: método para la determinación de la representatividad de un corpus, patente n. ES2320511 de la Universidad de Málaga, http:// umapatent.uma.es/es/patent/metodo-para-la-determinacion-de-la-representa4b0/ [Accessed 01/06/2016].

Even-Zohar, Itamar. 1999 La posición de la literatura traducida en el polisistema literario. Traducción de Montserrat Iglesias Santos revisada por el autor. In Iglesias Santos, Montserrat (ed.) Teoría de los Polisistemas. Madrid: Arco [Bibliotheca Philologica, Serie Lecturas], 223-231. 
Gil-Bardají, Anna. 2003. Procedimientos, técnicas, estrategias: operadores del proceso traductor. Recercat, Universitat Autònoma de Barcelona. http:// hdl.handle.net/2072/8998 [Accessed 16/04/2017].

Kenny, Dorothy. 2001. Corpus and Creativity in Translation. A Corpus-based Study. St. Jerome Publications.

Leech, Geoffrey. 1992. Corpora and theories of linguistic performance. In Svartvik, Jan (ed.) Directions in Corpus Linguistics. Proceedings of Nobel Symposium 82, Stockholm, 4-8 August 1991. Berlin/New York: De Gruyter.

Lepinette, Brigitte. La historia de la traducción. Metodología. Apuntes bibliográficos. HISTAL 2004. http://www.histal.ca/wp-content/uploads/2011/08/La-historia-de-la-traduccion-metodologia-apuntes-bibliograficos.pdf [Accessed 20/04/2017].

Mangiron i Hevia, Carme. 2006. El tractament dels referents culturals a les traduccions de la novel-la Botxan: la interacció entre els elements textuals $i$ extratextuals ( $\mathrm{PhD}$ thesis). Barcelona: Universitat Autònoma de Barcelona, Departamento de Traducción e Interpretación. http://hdl. handle.net/10803/5270 [Accessed 30/10/2014].

Mayoral Asensio, Roberto. 1994. La explicitación de la información en la traducción intercultural. In Hurtado A. (ed.) Estudis sobre la traducció. Castellón de la Plana: Publicacions de la Universitat Jaume I.

McEnery, Tony \& Wilson, Andrew. 1996. Corpus Linguistics. Edinburgh: Edinburgh University Press.

Molina Martínez, Lucía. 2001. Análisis descriptivo de la traducción de los culturemas árabe-español. Barcelona: Universitat Autònoma de Barcelona, Departamento de Traducción e Interpretación. http://hdl.handle. net/10803/5263 [Accessed 30/10/2014].

Molina Martínez, Lucía. 2006. El otoño del pingüino. Castellón de la Plana: Publicacions de la Universitat Jaume I.

Newmark, Paul. 1988. A Textbook of Translation. New York: Prentice Hall.

Nida, Eugene. 1945. Linguistics and Ethnology in Translation Problems. Word 1.

Nida, Eugene. 1964. Toward a Science of Translating: With Special Reference to Principles and Procedures Involved in Bible Translating. Leiden: Brill Archive.

Nord, Christiane. 1997. Translating as a Purposeful Activity. Manchester: St Jerome.

Piao, Scott et al. 2016. Lexical Coverage Evaluation of Large-scale Multilingual Semantic Lexicons for Twelve Languages. Proceedings of the 10th edition of the Language Resources and Evaluation Conference (LREC2016). Portoroz, Slovenia. 2614-2619. USAS Italian Semantic Tagger. http://ucrel.lancs.ac.uk/usas/gui/ [Accessed 20/04/17]. 
Procházková, Petra. 2006. Fundamentos de la lingüística de corpus. Concepción de los corpus y métodos de investigación con Corpus. www.prochazkova.de/fundamentos_de_la_ling $\% \mathrm{C} 3 \% \mathrm{BC} \% \mathrm{C} 3 \%$ adstica_de_corpus.pdf [Accessed 06/08/14].

Sánchez, Aquilino. 1995. Definición e historia de los corpus. In Sánchez, A.; Sarmiento, R.; Cantos, P. \& Simón, J. (org.) CUMBRE. Corpus lingüistico del español contemporáneo: fundamentos, metodología y análisis. Madrid: SGEL (Sociedad General Española de Librería).

Santamaria Guinot, Laura. 2001. Subtitulació i referents culturals. La traducció com a mitjà d'adquisició de representacions mentals. ( $\mathrm{PhD}$ thesis). Barcelona: Universitat Autònoma de Barcelona, Departamento de Traducción e Interpretación. http://hdl.handle.net/10803/5249 [Accessed 30/10/2014].

Sinclair, John. 1991. Corpus, Concordance, Collocation. Oxford: Oxford University Press.

Vázquez-Ayora, Gerardo. 1977. Introducción a la traductología: curso básico de traducción. Washington D.C.: Georgetown University Press.

Venuti, Lawrence. 1995. The Translator's Invisibility: A History of Translation. London: Routledge.

Xiao, Richard \& Ming, Yue. 2009. Using corpora in translation studies: the state of art. In Baker, P. 2012. Contemporary Corpus Linguistics. London: A\&C Black. 
